\title{
Glomerular Filtration Rate Calculation Based on Serum Creatinin and Cystatin C in Type 2 Diabetic Patients
}

\author{
Vu Thi Thom ${ }^{1, *}$ Vu Van Nga ${ }^{1}$, Do Thi Quynh ${ }^{1}$, Nguyen Thi Binh Minh², \\ Dinh Thi My Dung ${ }^{2}$, Le Ngoc Thanh ${ }^{1,2}$ \\ ${ }^{1}$ VNUH-School of Medicine and Pharmacy, 144 Xuan Thuy, Cau Giay, Hanoi, Vietnam \\ ${ }^{2}$ E hospital, 89 Tran Cung, Nghia Tan, Cau Giay, Hanoi, Vietnam
}

Received 03 August 2019

Revised 19 September 2019; Accepted 27 November 2019

\begin{abstract}
The incidence of type 2 diabetes mellitus is rapidly increasing, with many complications pressured on the health care system. Complications of diabetes due to chronic hyperglycemia related to other metabolic disorders, causing damage to the microvascular system. Among them, damaged kidney vessels lead to impair the renal function as diabetic nephropathy is the most common cause of end-stage renal disease. Measurement of glomerular filtration rate (GFR) is an important parameter in assessing renal function. In Vietnam's hospital, serum creatinine is the biomarker mostly used to assess GFR. However, this biomarker is affected many factors such as gender, age, ... Many studies showed that serum Cystatin $C$ is another biomarker that can detect early decline in GFR, less affected by other factors. Therefore, we conducted this study to explore serum cystatin $\mathrm{C}$ and creatinine levels in patients with type 2 diabetes and initially compare GFR in applying formulas of CKD.EPI 2012 and age and sex factors with these two biomarkers on those patient groups. The prospective, descriptive, cross-sectional study was performed on 50 patients with type 2 diabetes. Serum Cystatin C, serum creatinine test was performed and GFR was estimated by CKD.EPI 2012 equation. The results showed that the average serum Cystatin C level of the study group was $0.87 \pm 0.24 \mathrm{mg} / \mathrm{L}$ that expressed no difference between two genders, and significant difference between age groups. Whereas, the average serum creatinine level of the study group was $81.30 \pm 19.70 \mu \mathrm{mol} / \mathrm{L}$, significant difference between male and female but not difference between age groups. In patients with GFR $<60 \mathrm{~mL} / \mathrm{min} / 1.73 \mathrm{~m}^{2}$, serum creatinine and cystatin $\mathrm{C}$ levels were higher than normal but there was no difference with the upper limit in the normal reference range of the two indications.
\end{abstract}

Keyword: Type 2 diabetes, serum cystatin C, serum creatinine, glomerular filtration rate.

\footnotetext{
${ }^{*}$ Corresponding author.

Email address: thomtbk5@gmail.com
}

https://doi.org/10.25073/2588-1132/vnumps.4176 


\section{Introduction}

Nowadays, the incidence of diabetes is rapidly increasing. According to the statistics of the World Federation of Diabetes (2017), there are more than 400 million people with diabetes. It is estimated that by 2045 this number will increase by $1.1 \%$, equivalent to over 600 million people. Vietnam is one of the top countries with an estimated incidence of 2/1000 people in 2017 and an increase of 3.5/1000 people by 2045 [1]. In particular, type 2 diabetes accounts for more than $90 \%$ of diabetic patients [2]. Progressive diabetes causes many serious complications, major threats to health as well as the quality of life of patients. Complications of diabetes due to chronic hyperglycemia associated with other metabolic disorders, causing damage to the small blood vessel. Microvascular complications of diabetes include diabetic nephropathy, neuropathy and retinopathy. In particular, kidney damage is a common complication with the rate of $25.6 \%$ to $33.1 \%$ in Vietnam [3, 4]. Diabetic nephropathy causes renal structural abnormalities such as hypertrophy of the kidneys, an increase in basement membrane thickness, hyaline of kidney's vessels [5]. The functional alterations include a decrease in GFR, proteinuria, loss of kidney function [6]. GFR is the critical renal function. In clinical practice, estimating GFR using formulas base on serum creatinine is the most widely used method to assess kidney function [7]. In recent years, many studies show the disadvantages of using serum creatinine to measure GFR, this indicator has poor sensitivity among mild renal dysfunctional patients and it can be affected by other factors such as age, gender, BMI, race, etc. [8, 9]. Therefore, many studies have been conducted to evaluate GFR better, and cystatin C is one of the biomarkers recommended by the American Kidney Association to evaluate and classify chronic kidney disease [10]. Cystatin $\mathrm{C}$ is a substance produced at a constant rate by most cells with a nucleus, a low molecular weight protein with $\mathrm{M}=13,359 \mathrm{kDa}$ [11]. Cystatin $\mathrm{C}$ is normally filtered freely through the glomerulus and reabsorbed and metabolized in the renal tubule and the renal glomeruli freely filtered it. The renal tubules don't excrete and only an extremely small amount of cystatin $\mathrm{C}$ is excreted in the kidneys [7]. Therefore, the serum concentration of cystatin $\mathrm{C}$ is valuable to assess GFR and is not affected by factors such as diet, nutritional status, inflammatory state or other malignant diseases. Cystatin $\mathrm{C}$ in healthy adult ranges between $0.4-1.2 \mathrm{mg} / \mathrm{L}$ for both men and women $[12,13]$. There are many different GFR equations, Inker et al (2012) applied the equation to estimate GFR for 1119 subjects in 5 different studies and showed the GFR value of the combined formula between serum cystatin $\mathrm{C}$ and creatinine are more accurate and reliable [8].

In Vietnam, there have not been many studies evaluating the GFR based on serum creatinine and serum cystatin $C$ indicators, so we conducted this study to identify some factors such as age and gender related to serum cystatin $\mathrm{C}$ and serum creatinine concentrations as well as initial compare the GFR using the equation of CKD.EPI2012 of these two biomarkers in type 2 diabetic patients.

\section{Materials and methods}

Subjects of study: Type 2 diabetes out-patients treatment at the General Department of Internal Medicine - E Hospital. The CKD-EPI 2012 equations were used to calculate eGFR [14]. Two groups of patients were classified based on eGFR including eGFR $<60 \mathrm{~mL} / \mathrm{min} / 1,73 \mathrm{~m}^{2}$ and eGFR $>60 \mathrm{~mL} / \mathrm{min} / 1,73 \mathrm{~m}^{2}$.

Selection criteria: The patient has been diagnosed with type 2 diabetes (According to the Guidelines of the American Diabetes Association 2018) [15]; Full clinical information (age, gender), subclinical information (serum creatinine concentration, serum cystatin $\mathrm{C}$ concentration, serum glucose concentration) and voluntary participation in the study.

Exclusion criteria: The patients have one of the following criteria: acute illness; are treating thyroid diseases, taking thyroid medication in the last 6 months or being treated for corticosteroids; 
Time and place of study: The study was carried out from August 2018 to January 2019, data were collected from the Department of Biochemistry and Department of General Internal Medicine - E. Hospital.

Study methods: prospective, descriptive, cross-sectional study

Patients were examined and blood sampling for biochemical test. Serum Creatinine tests used Jaffee method with Olympus reagent (Germany), and serum Cystatin $\mathrm{C}$ test used turbidity measurements with Dialab reagent (Austria), both were performed on AU680 (Beckman Coulter, American) at the Department of Biochemistry of E. Hospital

Reference interval of two indicators [12,13]:

Serum Creatinine: man 74-110 $\mu \mathrm{mol} / \mathrm{L}$ woman: $58-96 \mu \mathrm{mol} / \mathrm{L}$

Serum Cystatin C: $0.4-1.2 \mathrm{mg} / \mathrm{L}$

Statistical analysis: Data were analyzed by SPSS 22.0 software (IBM, American). Analysis of variance (ANOVA); Chi-square tests $\left(\chi^{2}\right)$ and Pearson correlation were applied to the corresponding cases, Student's t-test was used to compare the means between two groups. P-value of less than 0.05 was considered as a statistically significant difference.

\section{Results}

\section{Serum cystatin $C$ and serum creatinine level}

The results of serum cystatin $\mathrm{C}$ and serum creatinine level in two gender groups were showed in table 1:

Table 1. Serum cystatin $C$ and serum Creatinine levels in two genders

\begin{tabular}{lllll} 
Indicator & $\begin{array}{l}\text { Man } \\
(\bar{x} \pm \mathrm{SD})\end{array}$ & $\begin{array}{l}\text { Woman } \\
(\bar{x} \pm \mathrm{SD})\end{array}$ & $\begin{array}{l}\text { Mean for all } \\
(\bar{x} \pm \mathrm{SD})\end{array}$ & $\mathrm{p}$ \\
\hline Serum Cystatin C $(\mathrm{mg} / \mathrm{L})$ & $0.92 \pm 0.25$ & $0.83 \pm 0.23$ & $0.87 \pm 0.24$ & 0.199 \\
Serum Creatinine $(\mathrm{mmol} / \mathrm{L})$ & $92.00 \pm 19.36$ & $74.23 \pm 16.79$ & $81.30 \pm 19.70$ & 0.01 \\
\hline
\end{tabular}

Men had higher serum creatinine levels than women, while there was no difference in serum cystatin $\mathrm{C}$ level in both genders. This is similar to the study of Weinert LS et al. (2010). This study performed on 97 healthy volunteers aged $18-40$ years, $44 \%$ are men, the result showed that gender had no effect on serum cystatin $\mathrm{C}$ level while there was a clear difference in creatinine levels in two genders $(p=0.001)$ [16]. In Vietnam, the study of Nguyen Thi Ly and Tran Thi Chi Mai (2012) on 90 patients with type 2 diabetes also showed no difference in cystatin C levels in both sexes [17]. Research on 3 groups of patients: with diabetes, thyroid and cardiovascular disease of Musaimi (2019) also found no difference in cystatin $\mathrm{C}$ concentration in both sexes. This research also showed that cystatin $\mathrm{C}$ is a useful biomarker for these diseases [18].

Relationship between serum creatinine, serum cystatin $C$ level and age

Table 2. Serum Cystatin C and Creatinine levels in age groups

\begin{tabular}{|l|l|l|l|l|l|}
\hline \multicolumn{2}{|c|}{ Age group } & $<60$ & $61-70$ & $>70$ & $\mathrm{p}$ \\
\hline $\begin{array}{l}\text { Serum cystatin C level }(\mathrm{mg} / \mathrm{L}) \\
(\bar{x} \pm \mathrm{SD})\end{array}$ & $0.701 \pm 0.089$ & $0.847 \pm 0.191$ & $1.046 \pm 0.286$ & $<0.001$ \\
\hline $\begin{array}{l}\text { Serum creatinine } \\
\text { level }(\mu \mathrm{mol} / \mathrm{L})\end{array}$ & \multirow{2}{*}{\begin{tabular}{l} 
Man \\
\cline { 3 - 6 }$(\bar{X} \pm \mathrm{SD})$
\end{tabular}} & $\mathrm{n}=5$ & $\mathrm{n}=9$ & $\mathrm{n}=6$ & 0.088 \\
\cline { 2 - 6 } & Woman & $\mathrm{n}=8$ & $\mathrm{n}=13$ & $\mathrm{n}=9$ & \\
& $69.975 \pm 9.218$ & $69.146 \pm 7.829$ & $85.378 \pm 25.603$ & 0.053 \\
\hline
\end{tabular}


Many studies showed that aging increases kidney problems $[19,20]$. To analyze the relationship between age and serum cystatin $\mathrm{C}$ levels, we divided our patients into three age groups: <60, $61-70,>70$-year-old. In each age group, we analyzed the concentration of serum cystatin $\mathrm{C}$ and serum creatinine, the results were shown in Table 2.

The results showed that serum Cystatin C levels increased with age $(p<0.001)$ and serum creatinine levels wasn't different between age groups ( $p=0.088$ in man, $p=0.053$ in woman).

The patients in our study were more than 40 years old. In this age, the physiological function tended to decrease, the ability to filter Cystatin C decreased, leading to an increase in serum Cystatin C level. This occurs because the kidneys also suffer from aging damage - a natural biological process [19]. Vascular disease affects the blood vessels in the kidneys, the loss of nephrons and the gradual decline of the cellular functions. All of these reasons can lead to renal tubular damage, decrease of GFR and increase the concentration of cystatin $\mathrm{C}$ in the blood.

Many studies showed that with age, there is a reduce in size and number of nephrons, changing tubulointerstitial and increasing glomerulosclerosis [20]. Thus, the increase of serum cystatin $C$ concentration with age may be the result of physiological decrease GFR.

With increasing age, there is the decrease in the function of kidney so that serum creatinine level increases. Other way, increasing age also decrease in muscle mass which also reduces the creatinine production. Thus, when the age increases, serum creatinine level usually does not respond timely with the degree of impairment kidney function [21]. After analyzing the relationship between these two indicators and age, we found that cystatin $\mathrm{C}$ was more valuable than creatinine in assessing the degree of renal physiological impairment with age.

Classification serum creatinine level and serum cystatin $C$ levels by the three CKD-EPI equations

According to the classification of KDIGO, the GFR below $60 \mathrm{~mL} / \mathrm{min} / 1.73 \mathrm{~m}^{2}$ is considered as reducing and kidney start to be damaged [14]. Classification the patients by GFR, we had the results of serum creatinine level and serum cystatin $\mathrm{C}$ level in table 3.

Table 3. Serum cystatin $\mathrm{C}$ level and serum creatinine level classify according to the equation $\mathrm{GFR}_{\mathrm{Cre}}, \mathrm{GFR}_{\mathrm{cys}}$, GFR $_{\text {cys-cre }}$

\begin{tabular}{|c|c|c|c|c|c|c|}
\hline \multicolumn{2}{|l|}{ Indicator } & GFR group & $\begin{array}{l}\text { Classify } \\
\text { according to the } \\
\text { equation } \mathrm{GFR}_{\text {cre }}\end{array}$ & $\begin{array}{l}\text { Classify } \\
\text { according to the } \\
\text { equation } \mathrm{GFR}_{\mathrm{cys}}\end{array}$ & $\begin{array}{l}\text { Classify } \\
\text { according to the } \\
\text { equation } \text { GFR }_{\text {cys- }} \\
\text { cre }\end{array}$ & $\mathrm{p}$ \\
\hline \multicolumn{2}{|c|}{$\begin{array}{l}\text { Serum cystatin } \mathrm{C} \\
\text { level } \\
(\mathrm{mg} / \mathrm{L}) \\
(\bar{x} \pm \mathrm{SD})\end{array}$} & $\begin{array}{l}\text { GFR }<60 \\
\mathrm{~mL} / \mathrm{min} / 1,73 \mathrm{~m}^{2} \\
\mathrm{GFR}>60 \\
\mathrm{~mL} / \mathrm{min} / 1,73 \mathrm{~m}^{2}\end{array}$ & $\begin{array}{l}(\mathrm{n}=8) \\
1.178 \pm 0.247 \\
(\mathrm{n}=42) \\
0.809 \pm 0.193\end{array}$ & $\begin{array}{l}(\mathrm{n}=8) \\
1.287 \pm 0.213 \\
(\mathrm{n}=42) \\
0.789 \pm 0.146\end{array}$ & $\begin{array}{l}(\mathrm{n}=7) \\
1.295 \pm 0.231 \\
(\mathrm{n}=43) \\
0.799 \pm 0.159\end{array}$ & 0.542 \\
\hline \multirow{2}{*}{$\begin{array}{l}\text { Serum } \\
\text { creatinine } \\
\text { level } \\
(\mu \mathrm{mol} / \mathrm{L}) \\
(\bar{x} \pm \mathrm{SD})\end{array}$} & Man & $\begin{array}{l}\mathrm{GFR}<60 \\
\mathrm{~mL} / \mathrm{min} / 1,73 \mathrm{~m}^{2} \\
\mathrm{GFR}>60 \\
\mathrm{~mL} / \mathrm{min} / 1,73 \mathrm{~m}^{2}\end{array}$ & $\begin{array}{l}(n=3) \\
125.133 \pm 14.425 \\
(n=17) \\
86.129 \pm 13.286\end{array}$ & $\begin{array}{l}(n=4) \\
115.225 \pm 20.299 \\
(n=16) \\
86.169 \pm 14.565\end{array}$ & $\begin{array}{l}(n=3) \\
120.200 \pm 21.669 \\
(n=17) \\
87.000 \pm 14.513\end{array}$ & 0.801 \\
\hline & Woman & $\begin{array}{l}\mathrm{GFR}<60 \\
\mathrm{~mL} / \mathrm{min} / 1,73 \mathrm{~m}^{2} \\
\mathrm{GFR}>60 \\
\mathrm{~mL} / \mathrm{min} / 1,73 \mathrm{~m}^{2}\end{array}$ & $\begin{array}{l}(n=5) \\
99.560 \pm 27.603 \\
(n=25) \\
69.172 \pm 7.299\end{array}$ & $\begin{array}{l}(n=4) \\
103.225 \pm 30.435 \\
(n=26) \\
69.777 \pm 7.788\end{array}$ & $\begin{array}{l}(n=4) \\
100.800 \pm 31.711 \\
(n=26) \\
70.150 \pm 8.718\end{array}$ & 0.983 \\
\hline
\end{tabular}


Patients with GFR $<60 \mathrm{~mL} / \mathrm{min} / 1.73 \mathrm{~m}^{2}$ had higher serum creatinine and serum cystatin $\mathrm{C}$ levels than the remaining patients and higher than the upper limit normal. If the GFR number was low, the kidney function was not well. Reducing the capacity of glomerular filtration make many substances stagnate so the concentration of these substances in blood increases. Thus, the concentration of serum creatinine and serum cystatin $C$ were high in the lower GFR group. This result agreed with the result of Oddoze et al. (2001) [22].

Table 3 showed that serum cystatin $\mathrm{C}$ level in patients with GFR $<60 \mathrm{~mL} / \mathrm{min} / 1.73 \mathrm{~m}^{2}$ was not different when calculated by 3 GFR equations. The results were similar with patients with GFR $>60 \mathrm{~mL} / \mathrm{min} / 1.73 \mathrm{~m}^{2}$ and with serum creatinine level in two groups of GFR. Besides, we found that patients with GFR $<60$ $\mathrm{mL} / \mathrm{min} / 1.73 \mathrm{~m}^{2}$ had the serum creatinine level and serum cystatin $\mathrm{C}$ levels higher than the normal reference range of these two indicators.

Serum creatinine level and serum cystatin $C$ level in patients with GFR $<60 \mathrm{~mL}$ $/ \mathrm{min} / 1.73 \mathrm{~m}^{2}$ compared with normal reference range

There was no difference in serum creatinine levels and serum cystatin $\mathrm{C}$ levels using 3 equations. Thus, we chose to compare these two markers with the upper limit of each indicator in patients with GFR $<60 \mathrm{~mL} / \mathrm{min} / 1.73 \mathrm{~m}^{2}$ when using the GFRcys-cre equation (The equation that uses both of these indicators). The results were shown in Table 4.

Table 4. Comparison serum cystatin $\mathrm{C}$ and serum creatinine levels with reference upper range in patients with GFR $<60 \mathrm{~mL} / \mathrm{min} / 1.73 \mathrm{~m}^{2}$ according to $\mathrm{GFR}_{\text {cys-cre }}$ equation

\begin{tabular}{|c|c|c|c|c|}
\hline \multicolumn{2}{|l|}{ Indicators } & $\begin{array}{l}\text { Mean } \\
(\bar{x} \pm \mathrm{SD})\end{array}$ & $\begin{array}{l}\text { Upper limit of } \\
\text { normal }\end{array}$ & $\mathrm{p}$ \\
\hline \multicolumn{2}{|c|}{ Serum cystatin C level (mg/L) } & $1.295 \pm 0.231$ & $1.2 \mathrm{mg} / \mathrm{L}$ & 0.318 \\
\hline Serum creatinine & Man & $120.200 \pm 21.669$ & $110 \mu \mathrm{mol} / \mathrm{L}$ & 0.501 \\
\hline level $(\mu \mathrm{mol} / \mathrm{L})$ & Woman & $100.800 \pm 31.711$ & $96 \mu \mathrm{mol} / \mathrm{L}$ & 0.782 \\
\hline
\end{tabular}

From the results of Table 4, we found that in the group patients with GFR $<60$ $\mathrm{mL} / \mathrm{min} / 1.73 \mathrm{~m}^{2}$ according to $\mathrm{GFR}_{\text {cys-cre }}$ equation, serum cystatin $\mathrm{C}$ and serum creatinine levels increased but has no significant difference with the upper limit of the normal reference range of these two indices. Thus, we have not found a difference in the changes in serum cystatin $\mathrm{C}$ and creatinine levels in patients with GFR $<60 \mathrm{~mL} / \mathrm{min} / 1,73 \mathrm{~m}^{2}$. This result was in line with the study of Oddoze et al. (2001). These authors also identified that serum cystatin $\mathrm{C}$ did not outperform serum creatinine methods to detect kidney damage [22]. A limitation in our study is that we only research on diabetic patients with a small number of patients, the results may not apply to patients with kidney damage due to other causes.

\section{Discussion}

\section{Serum cystatin $C$ and serum Creatinine levels in two genders}

Men had higher serum creatinine levels than women, while there was no difference in serum cystatin $\mathrm{C}$ level in both genders. This is similar to the study of Weinert LS et al. (2010). This study performed on 97 healthy volunteers aged $18-40$ years, $44 \%$ are men, the result showed that gender had no effect on serum cystatin $\mathrm{C}$ level while there was a clear difference in creatinine levels in two genders $(p=0.001)$ [16]. In Vietnam, the study of Nguyen Thi Ly and Tran Thi Chi Mai (2012) on 90 patients with type 2 diabetes also showed no difference in cystatin $\mathrm{C}$ levels in both sexes [17]. Research on 3 groups of patients: with diabetes, thyroid and cardiovascular disease of O.Al Musaimi (2019) also found no difference in cystatin $\mathrm{C}$ 
concentration in both sexes. This research also showed that cystatin $\mathrm{C}$ is a useful biomarker for these diseases [18].

\section{Relationship between serum creatinine, serum cystatin $C$ level and age}

The patients in our study were more than 40 years old. In this age, the physiological function tended to decrease, the ability to filter Cystatin C decreased, leading to an increase in serum Cystatin C level. This occurs because the kidneys also suffer from aging damage - a natural biological process [19]. Vascular disease affects the blood vessels in the kidneys, the loss of nephrons and the gradual decline of the cellular functions. All of these reasons can lead to renal tubular damage, decrease of GFR and increase the concentration of cystatin $\mathrm{C}$ in the blood.

Many studies showed that with age, there is a reduce in size and number of nephrons, changing tubulointerstitial and increasing glomerulosclerosis [20]. Thus, the increase of serum cystatin $\mathrm{C}$ concentration with age may be the result of physiological decrease GFR.

With increasing age, there is the decrease in the function of kidney so that serum creatinine level increases. Other way, increasing age also decrease in muscle mass which also reduces the creatinine production. Thus, when the age increases, serum creatinine level usually does not respond timely with the degree of impairment kidney function [21]. After analyzing the relationship between these two indicators and age, we found that cystatin $\mathrm{C}$ was more valuable than creatinine in assessing the degree of renal physiological impairment with age.

\section{Classification serum creatinine level and serum cystatin $C$ levels by the three CKD-EPI equations}

Patients with GFR $<60 \mathrm{~mL} / \mathrm{min} / 1.73 \mathrm{~m}^{2}$ had higher serum creatinine and serum cystatin $\mathrm{C}$ levels than the remaining patients and higher than the upper limit normal. If the GFR number is low, the kidney function is not well. Reducing the capacity of glomerular filtration make many substances stagnate so the concentration of these substances in blood increases. Thus, the concentration of serum creatinine and serum cystatin $\mathrm{C}$ are high in the lower GFR group. This result is similar to the result of Oddoze et al. (2001) [22].

Table 4 shows that serum cystatin $\mathrm{C}$ level in patients with $\mathrm{GFR}<60 \mathrm{~mL} / \mathrm{min} / 1.73 \mathrm{~m}^{2}$ is not different when calculated by 3 GFR equations. The results were similar with patients with GFR $>60 \mathrm{~mL} / \mathrm{min} / 1.73 \mathrm{~m}^{2}$ and with serum creatinine level in two groups of GFR. Besides, we found that patients with GFR $<60$ $\mathrm{mL} / \mathrm{min} / 1.73 \mathrm{~m}^{2}$ had the serum creatinine level and serum cystatin $\mathrm{C}$ levels higher than the normal reference range of these two indicators

Serum creatinine level and serum cystatin $C$ level in patients with GFR $<60 \mathrm{~mL}$ $/ \mathrm{min} / 1.73 \mathrm{~m}^{2}$ compared with normal reference range

From the results of Table 5, we found that in the group patients with GFR $<60$ $\mathrm{mL} / \mathrm{min} / 1.73 \mathrm{~m}^{2}$ according to $\mathrm{GFR}_{\text {cys-cre }}$ equation, serum cystatin $\mathrm{C}$ and serum creatinine levels increased but has no significant difference with the upper limit of the normal reference range of these two indices. Thus, we have not found a difference in the changes in serum cystatin $\mathrm{C}$ and creatinine levels in patients with GFR $<60 \mathrm{~mL} / \mathrm{min} / 1,73 \mathrm{~m}^{2}$. This result is similar to the study of Oddoze et al. (2001). These authors also identified that serum cystatin $\mathrm{C}$ did not outperform serum creatinine methods to detect kidney damage [22]. A limitation in our study is that we only research on diabetic patients with a small number of patients, the results may not apply to patients with kidney damage due to other causes.

\section{Conclusions}

Serum Cystatin C level in our patients depended on age where serum creatinine level depended on gender. Serum cystatin $C$ was more valuable than serum creatinine in assessing the degree of renal physiological impairment with 
age. Calculation of GRF based on serum cystatin $\mathrm{C}$ level or serum creatinine level or combine of both was not significant different in this study.

\section{Acknowledgements}

We would like to thank the sponsorship of the School of Medicine and Pharmacy, Vietnam National University, Hanoi for the project code CS.18.05; Thanks to the staffs of the School of Medicine and Pharmacy, VNU-Hanoi and E Hospital for supporting and facilitating us to carry out this study.

\section{References}

[1] N.H. Cho, J. Kirigia, J.C. Mnanya, K. Ogurstova, L. Gủaiguata, W. Rathmann, G. Roglic, N. Forouhi, R. Dajani, A. Esteghmati, E. Boyko, L. Hambleton, O.L.M. Neto, P.A. Montoya, S. Joshi, J. Chan, J. Shaw, T.A. Samuels, M. Pavkov, A. Reja, IDF Diabetes Atlas eight edition, International Diabete Federation, 2017. http://fmdiabetes.org/wpcontent/uploads/2018/03/IDF-2017.pdf (access 15 july 2019).

[2] G. Xu, B. Liu, Y. Sun, Y. Du, L.G. Snetselaar, F.B. $\mathrm{Hu}, \mathrm{W}$. Bao, Prevalence of diagnosed type 1 and type 2 diabetes among US adults in 2016 and 2017: population based study, British Medical Journal $361 \quad$ (2018) k1497. https://doi.org/ 10.1136/bmj.k1497.

[3] N.T.T. Minh, N.K. Luong, N.K. Son, The clinical and subclinical characteristics in patients with diabetes mellitus treated at Thai Nguyen General hospital, Journal of pratical medicine 787 (2011) 25-8.

[4] N.T.H. Lan, L.D. Tuan, Survey characteristics of renal complication in elderly type 2 diabetes outpatients treated at National Hospital of Endocrinology, Journal of Military Pharmacomedicine 62017 55-62.

[5] Mohsen Pourghasem, Hamid Shafi, Zahra, Histological changes of kidney in diabetic nephropathy, Caspian J Intern Med 6(3) (2015) 120-7.

https://www.ncbi.nlm.nih.gov/pmc/articles/PMC4 650785/pdf/cjim-6-120.pdf (access 16 july 2019).

[6] D.W. Powell, D.N. Kenagy, S. Zheng, S.C. Coventry, J. Xu, L. Cai, E.C. Carlson, P.N. Epstein,
Associations between Structural and Functional Changes to the Kidney in Diabetic Humans and Mice, Life Sci 93(7) (2013) 257-64. https://doi.org/ 10.1016/j.lfs.2013.06.016.

[7] Natalie Ebert, Elke Schaeffner, New biomarkers for estimating glomerular filtration rate, Journal of Laboratory and Precision Medicine 3(75) (2018. https://doi.org/10.21037/jlpm.2018.08.07.

[8] L.A. Inker, C.H. Schmid, H. Tighiouart, J.H. Eckfeldt, H.I. Feldman, T. Greene, J.W. Kusek, J. Manzi, F.V. Lente, Y.L. Zhang, J. Coresh, A.S. Levey, Estimating Glomerular Filtration Rate from Serum Creatinine and Cystatin C, The new England Journal of Medicine 367 (2012) 20-9. https://doi.org/ 10.1056/NEJMoa1114248.

[9] Ashwin Kumar, Anil Kumar, Serum cystatin C and serum creatinine levels in type 2 diabetes mellitus, International Journal of Research in Medical Sciences 3(1) (2015) 174-7. https://doi.org/10.5455/2320-6012.ijrms20150130.

[10] X. Jianguo, D.I. Broadhurst, M. Wilson, D.S. Wishart, Translational biomarker discovery in clinical metabolomics:an introductory tutorial, Metabolomics 9 (2013) 280-99. https://doi.org/ 10.1007/s11306-012-0482-9.

[11] B.T. Anh, Estimate the glomerular filtration rate by plasma creatinine and cystatin $\mathrm{C}$ concentration, Journal of Vietnam Medicine 2 (2012) 12-18.

[12] S. Kakde, S. Alexander, V.G. David, S. Jacob, A. Mohapatra, A.T. Valson, B. Gopal, C.K. Jacob, J. Hephzibah, V. Tamilarasi, S. Varughese, Relationship of creatinine and cystatin C-based estimated glomerular filtration rates with measured glomerular filtration rate in healthy kidney donors from South Asia, Indian J Nephrol 28 (2018) 34550. https://doi.org/ 0.4103/ijn.IJN 249_17

[13] Olympus life science research europa $\mathrm{GmbH}$, Olympus clinical chemistry reagent guide, Olympus Diagnostic, American, 2009.

[14] International Society of Nephrology, KDIGO 2012 clinical practice guideline for the evaluation and Management of chronic kidney disease, Kidney Int, Kidney International Supplements 3(1) (2012) 5-14. https://kdigo.org/wpcontent/uploads/2017/02/KDIGO_2012_CKD_G L.pdf (access 19 july 2019).

[15] American Diabete Association, Classification and Diagnosis of Diabetes: Standards of Medical Care in Diabetes 2018. Diabetes Care, (41(Supplement 1)) (2018) S13-S27. https://diabetesed.net/wpcontent/uploads/2017/12/2018-ADA-Standardsof-Care.pdf (access 18 july 2019). 
[16] L.S. Weinert, A.B. Prates, F.B. do Amaral, M.Z. Vaccoro, J.L. Camargo, S.P. Silveiro, Gender does not influence cystatin $\mathrm{C}$ concentrations in healthy volunteers, Clin Chem Lab Med 48(3) (2010) 4058. https://doi.org/10.1515/CCLM.2010.068.

[17] N.T. Ly, T.T.C. Mai, Serum cystatin C and renal function in type 2 diabetic patients, Journal of medical Research 80(3B) (2012) 17-O.Al.

[18] Musaimia, A.H. Abu-Nawwas, D.Al. Shaera, N.Y.Khaleela, M.Fawzi, Influence of age, gender, smoking, diabetes, thyroid and cardiac dysfunctions on cystatin $\mathrm{C}$ biomarker, Medicina de Familia Semergen 45(1) (2019) 44-51. https://doi.org/ 10.1016/j.semerg.2018.07.005.

[19] M.C. Odden, I.B. Tager, R.T. Gansevoort, S.J.L. Bakker, R. Katz, L.F. Fried, et al, Age and cystatin $\mathrm{C}$ in healthy adults: a collaborative study, Nephrol
Dial Transplant 25(2) (2010) 463-9. https://doi.org/10.1093/ndt/gfp474.

[20] E.D. O' Sullivan, J. Hughes, D.A. Ferenbach, Renal Aging: Causes and Consequences, J Am Soc Nephrol 28 (2017) 407-20. https://doi.org/10.1681/ASN.2015121308.

[21] E.D. O' Sullivan, J. Hughes, D.A. Ferenbach, Renal Aging: Causes and Consequences, J Am Soc Nephrol 28 (2017) 407-20. https://doi.org/10.1681/ASN.2015121308.

[22] Christiane Oddoze, Henri Portugal, Yvon Berland, Bertrand Dussol, Cystatin C Is Not More Sensitive Than Creatinine for Detecting Early Renal Impairment in Patients With Diabetes. American Journal of Kidney Diseases, 38(2 (August)), (2001) 310-6. https://doi.org/ 10.1053/ajkd.2001.26096. 